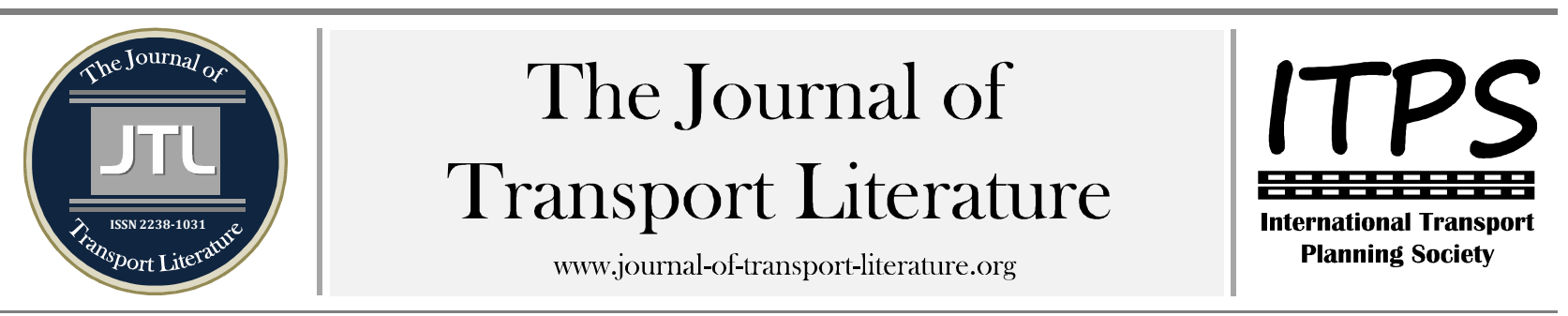

\title{
The Institutional Framework Surrounding Agricultural Transportation Policy in Nigeria
}

Akunna Oledinma

Glasgow Caledonian University, Glasgow, UK

\section{Article Info}

Keywords:

Nigeria

government

infrastructure

transportation

policy

Submitted 2 May 2014;

received in revised form 27 Jun 2014

accepted 10 Aug 2014

Licensed under

Creative Commons

CC-BY 3.0 BR

\begin{abstract}
Despite the potential of agriculture in Nigeria, transport infrastructure projects in Nigeria have been adversely affected by poor policy formulation. This paper presents transportation infrastructure management within the past years in Nigeria and identifies that poor integration and management of the transportation sector with other productive sectors of the economy. For example from 2009 to 2011 budgets, the transport sector had the lowest allocation which was approximately 10 billion naira while other sectors-Education, Power; Works and Housing, and Urban Development had 60 billion, 18 billion and 35 billion naira respectively. Despite the low allocation on the average, transport had the highest budget-performance index of $37.29 \%$, and therefore the highest performance rate. Research on transportation infrastructure development in Nigeria is not new, however; understanding transportation integration and management with other productive sectors of Nigerian economy is still under-researched. Data on transportation and agriculture investment are not readily available despite its importance in national development. Integration between state and federal governments' activities was recommended to identify the resource areas within the state to make policies that would enhance the income of both the state and those involved in fiscal generation.
\end{abstract}

+ Corresponding author. School of Engineering and Built Environment, Glasgow Caledonian University, Glasgow, G4 0BA, UK.

E-mail address: akunna.oledinma@gcu.ac.uk.

\section{Introduction}

This paper analyses the current transport infrastructure policy in Nigeria in particular its implementation and effect on agriculturally-dominant rural areas in the country. The key objective is to analyse and understand Nigeria's transport infrastructure and identify problems associated with it (systems and polices), and how these difficulties affects the inhabitants. The qualitative method was therefore used to analyse these assertions and better implementation was suggested.

Although infrastructural quality and availability support national development (Holm-Hadulla, 2005;Familoni et al. 2002), government commitment through the development and implementation of policy is equally vital especially in determining such infrastructure project continuity and success. Generally government effort in infrastructure development and project management in Nigeria has been surrounded by propagandas. Although there has been some effort in infrastructure development in the country lately, evidently, such efforts have not been adequately extended to the transport sector.

As an agrarian country, Nigeria's transportation infrastructure projects which support development are inadequate; this stems from poor policy formulation. Furthermore, project discontinuity in transportation is still challenging government administration in Nigeria: for instance, the failed privatization of the railways to curb problems of monopoly. Such investment failure was due to corruption, politics and poor government administration. Total commitment to the provision of transport infrastructure network for economic growth was often considered unimportant. Agricultural transportation encompasses political, social and economic components; consequently, the commitment of both government and planners through efficiently analyzing and planning is required in the decision-making process for agricultural transportation to benefit locals (Crainic and Laporte, 1997). A clear understanding of the structure (historical and existing) of the government institution is pivotal to the effectiveness of a sustainable transportation system (Starkey, 2002).

Research on transportation infrastructure development in Nigeria is not new (Mijinyawa and Adetunji, 2005; Odugbemi et al. 1998; Filani, 1993; Aloba, 1986), however; understanding its management as it relates to interrelationship of agriculture and transportation is still under-researched. Little is known about transportation integration and management with other productive sectors of Nigerian economy. Consequently the findings of this study are summarised as follows:

- Insufficient commitment by the government in transportation infrastructure provision which stems from poor transportation policy development and its implementation. Such indifference by the government also affects older infrastructure, which is not considered for adequate maintenance, adversely affecting agricultural transportation;

- Problems with the continuity of projects developed by previous administrations stemming from political or economic expediency which has reduced the railways' profitability and subsequently loss of revenues for the government; 
- Poor integration and management of the transportation sector with other productive sectors of the economy which has hindered the optimal performance of agricultural transportation in Nigeria.

The paper will firstly discuss a brief history of transport policy in Nigeria. Afterwards the major problems of major modes of transport-road and rail will be discussed. This is followed by summary and conclusion of the issues in Nigeria's transport policy emphasizing the need for government in developing countries like Nigeria should understand program design prior to making policy.

\section{The current state of transport infrastructure provision in Nigeria and its associated problems: rail transport}

\subsection{Discontinuity within the transportation institution}

The monopolistic structure of the railways was blamed for a series of challenges which had confronted it since its establishment in 1912. The most recent of these challenges was in 2006 (Nigerian Railway Corporation, 2011). \$60bn was invested by the Federal Government of Nigeria (FGN) in the railways with the expectation that such investment would increase its profitability and subsequently generate revenues for the government. This project was a 25-year plan. Ford (2004) points out that this plan was to extend the rail network and connect major commercial centres within the country. He argued that this was a major step in the right direction for a long term project but what was uncertain was whether the regime that started this project would be around to either bear responsibility for its failure or take the credit for its success.

In 2001, the Ministry of Finance with the supervision of the Bureau of Public Enterprise (BPE), proposed to privatise the railways with the intention of curbing the problems of monopoly but was unsuccessful. The reasons for this failure were unclear. There was much speculation by the media about corruption within the administration and investors were sceptical on likely profitability because of the huge debt already incurred by the NRC. In 1995, a bilateral agreement for improvement of the infrastructures and operations of railways between the Chinese Government and the FGN did not develop, because the regime that signed the agreement lasted only two years and was ended by the sudden death of the president. This discontinuity was often inexplicable but could possibly be associated with either political or economic expediency, thus leading to persistent abandonment of railway project over two decades.

\subsection{Characteristics of commitment in making policy and consequently infrastructure provision}

The lack of integration emanating from the political and historical development of the railway does not show sincere commitment in sustainable or integrated transport policy making as claimed by Nigeria's National Transportation Policy. There is a lack of rail/road competition which would have otherwise reduced freight rate for movement by the road. Freight movement within a locality or region favours long distance imports (these are relatively cheaper than the local produce) from overseas continents like Europe and North America, to the detriment of transport between a locality, region or country. Simply put, an attempt to move freight within the same continent (Africa in this case) is hindered due to high cost of conveying freight within a reasonable short distance.

Generally, where local transportation is not encouraged to facilitate the activities of the local market for agricultural produce due to competition from imports, the infrastructure meant to support transportation for local market activities is not provided. This is because the government is often reluctant to invest in the development of local transportation systems. In the absence of this investment the private sector will have no incentive for investment in transport either because of its expensive or unattractive nature. Consequently, the attention of the private sector is diverted towards investing in trucking (which has become the common method of transportation for local business in Nigeria. Importantly, the movement of imports from the ports to the desired destination is often done by road and the continuous usage of road for this purpose explains why the use of railway transportation has been undermined and viewed as unattractive with no significant benefits.

\section{The role of the railways in identifying the interrelationship between agriculture and transportation}

Railways have the ability to effectively distribute goods, and transport passengers locally and develop markets for goods export (Omiunu, 1987; Limi and Smith 2007). Evidently, where optimal utilisation of railway transportation occurs, there is tendency for market activities for agricultural produce within the country to improve. The realisation of this improvement is pivotal on the interdependence between rail transportation and agricultural activities, which has not been achieved so far in Nigeria. There is no significant investment in the railways irrespective of its contribution to agricultural distribution. For example, the Nigerian railway system was designed around an agrarian economy. Given that the railway freight depended on agriculture, the interdependence between rail transportation and agriculture had already been established. There have been a few failed attempts at railway investment with the potential of generating profit and consequently integration with agriculture. The most recent was a $\$ 60 \mathrm{bn}$ investment in 2006 with the expectation that such investment would increase its profitability and subsequently generate revenues for the government (Nigerian Railway Corporation, 2011). This project was discontinued. In 1995, a bilateral agreement for improvement of the infrastructures and operations of railways between the Chinese Government and the FGN did not take off. The reason surrounding this was that problem of discontinuity concerning projects in Nigeria (Mailafia, 2002).

The impact of such lack of investment in the railway reflects on the declining passenger and freight capacity in Nigeria between 1970 and 2004. For passenger transport, averge decline for this period was 68\% while freight transport declined by $80 \%$ (Odeleye, 2010). Inconsistency in government investment meant that traffic was diverted to the road (by the private sector) to prevent loss of their business stemming from delays due to unreliable timetable and poor state of the locomotives. Although the diversion sustained the provate sector, it created an unhealthy rail/road competition (Odeleye, 2011). The Nigerian railways are still running at a loss.

Arguably, the railway system is historically the single economic initiator, the main reason for expansion of the agricultural export produce sector in an agrarian country and the main factor widening markets (Rostow, 1971 p. 76). This statement is true not only in developed countries as suggested by Rostow (1971) but also in developing countries like Nigeria. It reflects in the growth of the agricultural trade sector in Nigeria for the export of palm produce, cocoa and 
groundnut prior to the oil boom, at which time the railway system was fully operational in the country. Hilling (1996) explained that the railway was one of the first alternatives to human portage in Africa. This is evident in that the development of the railway system was an initiator of long distance travel in Nigeria preceding the road mode.

There is no strong justification, whatever the reasons were, for the abandonment of rail projects in Nigeria for other modes of transport. According to Limi and Smith, J. (2007) if agricultural produce is to be mass transported, then railways are an essential infrastructure to develop. This development should be interconnected with the road for optimum operation and seamless flow of traffic.

\subsection{The current state of transport infrastructure provision in Nigeria and its associated problems: road}

$90 \%$ of freight movement in Nigeria is dominated by road (OECD, 2006). Integrating road network with other modes of transport-rail, sea, air-enhances economic agricultural produce distribution, which is high-volume/low-value. Such integration has not been realised in Nigerian Transport Policy, hence not explicitly highlighted. In 1924, the Nigerian trunkroad policy was developed grading roads into 3-trunks 'A', 'B' and 'C' (Akinbami and Fadare, 1997). Trunk 'A' road was under the jurisdiction of the Federal Government and was built to link the federal to the state capital and other major towns. Trunk ' $\mathrm{B}$ ' road was the responsibility of the state government connecting the divisional headquarters and other larger towns with the trunk ' $A$ ', while trunk ' $C$ ' was under the jurisdiction of the local government. This appeared to be a thoroughly conceived plan, but was saddled with problems.

Out of the $193,200 \mathrm{~km}$ of roads, $32,100 \mathrm{~km}(17 \%)$ were Federal roads or trunk A roads, trunk B roads comprised $30500 \mathrm{~km}(16 \%)$ and belonged to the state, while $130,600 \mathrm{~km}(67 \%)$ of rural roads were trunk $\mathrm{C}$ and were under the jurisdiction of the local governments (Federal Ministry of Transport, Nigeria 2010). These three tiers were accordingly responsible individually for planning, maintenance and financing. The financial responsibilities were not allocated in this order. The local government with had the smallest monetary allocation, while the federal and state with lower share of responsibilities were assigned the highest share of funds (Federal Ministry of Transport, Nigeria, 2010). Consequently, neglect of maintenance, and faulty design and construction was faced by the rural areas stems from this anomaly (Akinbami and Fadare, 1997).

This suggests that the transport problems such as misuse of roads, neglect of maintenance, and faulty design and construction faced by the rural areas stems from this anomaly (Akinbami and Fadare, 1997). The new plan by the Federal government to revise these shows that road fund allocation will be revised as follows: Local Government 50\%: State 30\%: Federal 20\%. This strategy is still not justified.

\section{Budget allocation pattern in Nigeria between the key sectors of the economy}

\subsection{Comparison of transport budget allocation with that of other priority sectors}

Agriculture, education, transport and health are the key sectors of the Nigerian economy and are given priority in the FGN budget. These sectors vary depending on policy preferences of the current regime (Federal Ministry of Finance, Nigeria, 2012). For the 2009-2011 budget, the key sectors, identified as shown in Table 1, are: Agriculture and Rural Development; Education; Health; Power; Transport and; Works and Housing; and Urban Development. Overall Transport sector has the lowest allocation within this time period: the lowest allocation was in 2011 which was approximately 10 billion naira.

\begin{tabular}{|c|c|c|c|c|c|c|c|c|c|c|c|}
\hline \multirow[t]{2}{*}{ Sector } & \multicolumn{3}{|c|}{2009} & \multicolumn{3}{|c|}{2010} & \multicolumn{3}{|c|}{2011} & \multirow{2}{*}{$\begin{array}{c}\text { Average } \\
\text { budget } \\
\text { allocation }\end{array}$} & \multirow{2}{*}{$\begin{array}{c}\text { Average } \\
\text { performance } \\
(\%)\end{array}$} \\
\hline & Budget & Implemtn* & $\begin{array}{l}\text { Performance } \\
(\%)\end{array}$ & Budget* & Implemtn* & $\begin{array}{l}\text { Performance } \\
(\%)\end{array}$ & Budget* & Implemtn* & $\begin{array}{l}\text { Performance } \\
(\%)\end{array}$ & & \\
\hline $\begin{array}{l}\text { Agriculture } \\
\text { and Water } \\
\text { Resources }\end{array}$ & 46687 & 27476 & 59.01 & 77894 & 58544 & 73.20 & 7763 & 3656 & 47.90 & 44114 & 60.04 \\
\hline Education & 16134 & 6581 & 40.83 & 33363 & 24412 & 34.71 & 6016 & 2048 & 34.05 & 18504 & 36.53 \\
\hline Health & 18211 & 4727 & 26.04 & 33570 & 32769 & 97.64 & 8230 & 3784 & 45.98 & 20003 & 56.56 \\
\hline Power & 43827 & 5779 & 13.18 & 70126 & 47509 & 67.80 & 18134 & 9347 & 51.54 & 44029 & 44.17 \\
\hline Transport & 31405 & 8725 & 27.78 & 44311 & 22380 & 50.5 & 10946 & 3662 & 33.58 & 28887 & 37.29 \\
\hline $\begin{array}{l}\text { Works and } \\
\text { Housing }\end{array}$ & 130484 & 49265 & 37.76 & 127872 & 99577 & 60.19 & 34048 & 15612 & 88.06 & 97468 & 62 \\
\hline
\end{tabular}

Source: Budget Office of the Federal Ministry of Finance; 2009-2011. *Figures in billions of naira.

Table 1 above illustrates a comparison of percentage of allocation of budget in transport and other priority sectors from 2009 to 2011. Out of the key sectors of the economy; agriculture and rural development, transport, education and works, achieved some targets. Health achieved an average performance rate of $56.56 \%$ with an average allocation of 20 billion naira while education achieved an average performance of $36.53 \%$ with an average allocation of 18.5 billion naira. On the average, with the exception of the health and education sector, transport had the highest budget-performance index of $37.29 \%$ - the highest performance rate. Although this average calculation may demonstrate optimistic picture of the transport sector, the lowest allocation was to this sector despite its performance. Arguably, because of the weather-related 
implementation of transportation projects, these would be higher (Federal Ministry of Finance, 2010). The Ministry of Finance argues that the poor performance of the ministries was also due to the poor project management, costing as well as poor planning. But why has budgetary allocation to transport been extremely poor compared to other priority sectors, despite this performance?

Prediction-spending (Mortensen, 2009) of the key sectors of the economy means that improving the quality of life and welfare of the citizens were miscalculated by the FGN; efficiently performing sectors within the critical sectors were not given prioritised. Is the paltry sum allocated to the transport budgets a result of competing claims from recent merging sectors (such as Power, Works and Housing), or is it a result of poor monitoring and evaluation as stated by the Budget (Ministry of Finance, 2010)? The transport sector needs more budgetary allocation as a result of its interrelationship with other productive sectors regardless of the reasons given by the Ministry of Finance.

\section{Conclusion}

The paper has identified issues which constrain the development of such agricultural transportation in developing countries like Nigeria. Two of the most significant factors were poor commitment by the government in infrastructure provision especially in the agriculturally dominant rural areas and poor integration and management of the transportation sector with other productive sectors of the economy. For example for 2009 to 2011 budgets, the transport sector has overall the lowest allocation within this time period: the lowest allocation was in 2011 which was approximately 10 billion naira while other sectors-Education, Power; Works and Housing, and Urban Development had 60 billion, 18 billion and 35 billion naira respectively. Despite the low allocation on the average, transport had the highest budget-performance index of $37.29 \%$, and therefore the highest performance rate. Such low allocation neither show support for the activities of the transport sector nor commitment by the government. The key issues for the paper can therefore be concluded as follows:

- Insufficient commitment by the government in transportation infrastructure provision which stems from poor transportation policy development and its implementation. Such indifference by the government also affects older infrastructure, which is not considered for adequate maintenance, adversely affecting agricultural transportation.

- Problems with the continuity of projects developed by previous administrations stemming from political or economic expediency which has reduced the railways' profitability and subsequently loss of revenues for the government.

- Poor integration and management of the transportation sector with other productive sectors of the economy which has hindered the optimal performance of agricultural transportation in Nigeria.

The recommendation here is therefore not exhaustive but is aligned to the identified problems in this study. Making policy is insufficient, it needs to be implemented. The federal government should work with the state government to identify the resource areas within their state and make policies that would enhance the income of both the state and those involved in fiscal generation. For example, policy on agricultural transportation should be more explicit and focused on its agents-consumers, farmers, traders, transporters-and complemented by efforts from the related ministries (Agriculture, Commerce and Industry, Transport and Economic Planning). Over the years agricultural policies have been nationally focused. The recognition of the potential of agriculture should drive government policies towards strategies that could increase productivity. This could involve engaging with the private sectors in certain areas: crop production, transportation, and marketing of the produce nationally and internationally. The extension of the political tenure in Nigeria from four to eight years would ensure that politicians-and their cabinet members-have sufficient time to plan and execute their mandate. The current four year tenure is insufficient to make and execute crucial long-term policies regarding economic development. This may seem a very impracticable suggestion because Nigeria's political system has been, historically, dominated by rigidity. Such rigidity precipitated the administrative structure of the ministries and despite its ineffectuality this system has remained stubbornly resistant to change. It is commonly regarded that one consequence of this is corruption which favours those in authority and who refuse to make changes they would deem personally disadvantageous. However, this is still conceivably an improvement on the military regime's stranglehold which obtained prior to the adoption of Nigeria's democratic system in 1992. Importantly, this is a scientific exercise and this could be a possible limitation of this research.

Very little research in understanding the interrelationships between transport and agriculture in Nigeria has been carried out, considering the significance of such relationship one wonders why such a study has not been critically examined. Given that Nigeria is an agrarian country, such a study is very vital. The analysis in this study has been from a policy view point, a quantitative evaluation is required as a comparator of the findings in agriculture and transportation interrelationship. Such comparison could be what percentage of transport investment would be required to yield the required output in Nigeria. Further study - in agricultural producing areas-in Nigeria is required to actually identify the stakeholders and their problems and a well-conceived pattern of communication.

Another limitation of this research is that reference to transport was on only two modes (road and rail). There is need to study the issues in the water and air transport to provide more robust conclusion. Agricultural statistics are vital in a study like this. Data transportation and agriculture investment are not readily available. Current information from Nigeria's data bank such as that from the National Bureau of Statistics is not easily accessible, and usually incomplete. This data gap is a common problem with developing countries (You et al. 2007).

\section{References}

Akinbami, J. F. K., \& Fadare, S. O. (1997), Strategies for sustainable urban and transport development in Nigeria. Transport Policy, 4(4), 237245.

Aloba, O. (1986), Rural Transportation' in Falola T., \& Olanrewaju S. A. (eds.) Transportation system in Nigeria. Maxwell School of Citizenship and Public Affairs, Syracuse University, 125-138.

Central Bank of Nigeria (2011), CBN annual reports and statement of accounts.

Crainic, T.G., \& Laporte, G. (1997), Planning models for freight transportation. European Journal of Operational Research, 97(3), 409-438.

Dandago, K. I., Familoni, K. A., Mailafia, D. I., Oyeranti, O. A., Ukwu, I. U., \& Yusuf, M. O. (2002), Infrastructural development and economic growth in Nigeria. Conference proceeding, Bauchi, Nigeria, 1-40. 
Federal Government of Nigeria, Federal Ministry of Finance. (2010), The Nigerian Budget. Retrieved March 14, 2012 from www.budgetoffice.gov.ng.

Federal Ministry of Finance, Nigeria (2012), The Nigerian budget: 2008. Available at: www.budgetoffice.gov.ng.

Federal Ministry of Transport, Nigeria. (2010), Draft of National Transport Policy.

Filani, M. O. (1993), Transport and rural development in Nigeria. Journal of Transport Geography, 1(4), 248-254.

Ford, N. (2004), Nigeria: Ambitious makeover plans for transport. African business, 297, 50.

Hilling, D. (1996), Transport and developing countries, Routledge: New York.

Howe, J. (1975), The future of surface transport in Africa. African Affairs, 74(296), 314-325.

Limi, A., \& Smith, J. W. (2007), What is missing between agricultural growth and infrastructure development: Cases of coffee and diary in Africa. Nov. 11.

Mijinyawa, Y., \& Adetunji, J. (2005), Evaluation of farm transportation system in Osun and Oyo states of Nigeria. Agricultural engineering international: The CIGR ejournal, 7.

Mortensen, P. B. (2009), Political attention and public spending in the United States. Policy Studies Journal, 37(3), 435-455.

National Bureau of statistics, Nigeria (2010), The Transport sector. Available at www.nigerianstat.gov.ng.

Nigerian Railway Corporation (2011), History of Nigerian railway.

Odeleye, J. A. (2010), Politics of rail transport development in developing countries: A case of Nigeria. Lisbon, Portugal, 15 Sep, 1-20.

Odeleye, J. A. (2000), Public-private participation to rescue railway development in Nigeria. Japan Railway and Transport Review, 23, 4249.

Omiunu, F. (1987), Towards a transport policy for the ECOWAS sub-region. Transport reviews, 7(4), $327-340$.

Odugbemi, O. O., Ajiboye, A. O., \& Onakomaiya, S. O. (1998) Transport factor in cash crop production and distribution: The Kolanut example. Journal of Transport Studies, 2(1).

Organisation of Economic Community Development, (2006), Economic country profile of Nigeria. Available at www.africaneconomicoutlook.org.

Rostow, W. W. (1971), The stages of economic growth a non-communist manifesto. 2nd edn. Cambridge: CUP.

Starkey, E. A. (2002), Improving rural mobility: Options for developing motorized and non-motorized transport in rural areas. World Bank technical paper, 525, 1-61.

You, L., Wood, S., Wood-Sichra, U., \& Chamberlin, J. (2007), Generating plausible crop distribution maps for sub-Saharan Africa using a spatial allocation model. Information development, 23(2-3), 151-159. 